\title{
ROLE OF GANGLIOSIDES IN GONADOTROPIN AND CHOLERA ENTEROTOXIN STIMULATED STEROIDOGENESIS IN ISOLATED RAT OVARIAN CELLS*
}

\author{
Salman Azhar, Paul Fitzpatrick and K.M.J. Menon \\ Endocrine Laboratory, Departments of Obstetrics and Gynecology \\ and Biological Chemistry, The University of Michigan Medical School \\ Ann Arbor, Michigan 48109
}

\section{Received May 4,1978}

Summary: Ovarian cells isolated from 26 day old rats responded to hCG $(10 \mathrm{ng} / \mathrm{ml})$ and cholera enterotoxin $(100 \mathrm{ng} / \mathrm{ml})$ in vitro with a forty-five to fifty-fold increase in progesterone production. Both cholera enterotoxin and hCG-stimulated progesterone response was accompanied by a lag period. The duration of the lag period in the production of the progesterone depended on the concentration of gonadotropin or cholera enterotoxin, and with maximally stimulating dose it was 20-30 minutes. Addition of highiy purified mixed gangliosides to the incubation medium abolished the stimulatory effect of cholera enterotoxin on progesterone response. In contrast, under identical experimental conditions, ganglioside addition produced no effect on progesterone response elicited by hCG or LH. Similarly mixed gangliosides did not prevent the specific binding of $\left[{ }^{125}\right.$ I $]$ hCG to the ovarian cells or to the membranes isolated from the ovary. In addition preincubation of [125 I]hCG with ganglioside did not alter the subsequent binding of the hormone to the ovarian cell surface receptor. These findings suggest that gangliosides are not involved in the hormone receptor interactions and subsequent receptor mediated physiological response.

Recent evidence suggests that the steroidogenic action of gonadotropin in the ovary is triggered by its interaction with cell surface receptors $(1-6)$ and this interaction results in the stimulation of adenylate cyclase (ATP pyrophosphate lyase [cyclising] EC 4.61.1). The subsequent increase in the intracellular cyclic AMP leads to activation of protein kinase and steroidogenesis (7-11). Cholera enterotoxin, a nonhormonal agent which is known to elevate intracellular cAMP levels in a variety of systems $(12,13)$, also

Abbreviations: hCG, human chorionic gonadotropin; LH, luteinizing normone; $\mathrm{G}_{\mathrm{M}}$, galactosyl-N-acetylga lactosaminy $1-[\mathrm{N}$-acetylneuraminyl]-gal actosy $\mid \mathrm{gl}$ ucosyl ceramide; $G_{0}-\mathrm{N}$-acety $\mid$ neuraminyl-ganactosy $1-\mathrm{N}$-acetylgal actotosaminy $1-[\mathrm{N}-$ acety Ineuramingl ${ }_{\text {-gà }}$ actosylgl ucosylceramide; $G_{0}$, ga lactosyl-N-acetylgal actosaminy $1-[\mathrm{N} \text {-acety } 1 \text {-neuraminy } 1-\mathrm{N} \text {-acetyl neuraminy } 1\}^{\prime}$-ga l actosy $1 \mathrm{gl}$ ucosyl cerami de ;

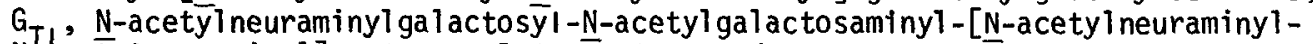
N-d cetylneuraminyl]-galactosylgl ucosylceramide.

* This work was supported by a grant(HD06656) from the National Institutes of Health. PF is supported by NIH Predoctoral training grant GM00187. 
stimulates protein kinase activity in the ovary by elevating cyclic AMP levels (11). The existence of sequence analogies between cholera enterotoxin and other peptide hormones such as TSH, LH, hCG and FSH $(14,15)$ suggests that the cell surface receptors for all glycoprotein hormones may have identical structure, and that these peptide hormones might share a similar mechanism of receptor interaction, possibly through the involvement of glycosphingolipids. Recent studies of Lee et al, $(16,17)$ on the inhibition of $[125 \mathrm{I}] \mathrm{hCG}$ and $\left[{ }^{125} \mathrm{I}\right]$ LH binding to rat testes plasma membranes by gangliosides further support this possibility $(16,17)$. However, no direct studies have so far been performed to test whether gonadotropin ganglioside interaction leads to altered cellular function including steroidogenesis in the ovary.

In an attempt to answer these questions, in the present study, we have investigated the effect of gangliosides on [ ${ }^{125}$ I $]$ hCG binding and gonadotropinstimulated steroidogenesis in rat ovarian cells. The system we utilized is the collagenase dispersed ovarian cells. Previous studies from this laboratory have demonstrated the binding of $\left[{ }^{125} \mathrm{I}\right] \mathrm{hCG}$ and a dose dependent in vitro stimulation of cAMP accumulation, protein kinase and progesterone synthesis in these cells. We report here that although the addition of gangliosides did block cholera enterotoxin stimulated progesterone production by the ovarian cells, it was ineffective to block gonadotropin stimulated steroidogenesis. Neither did the sphingolipid block the bunding of ${ }^{125}$ I-hCG either to the ovarian cells or to membranes, underscoring the extreme specificity of hormone receptor for gonadotropin.

\section{MATERIALS AND METHODS}

Twenty-six day old female (Spartan) rats were used in the present experiment. Collagenase dispersed ovarian cells were prepared as described previously (7-10). Human chorionic gonadotropin (hCG) was a gitt of the Center for Population Research, NICHD, Bethesda, MD and provided by Dr.R.E.Canfield of Columbia University, New York. Bovine brain mixed gangliosides and cholera enterotoxin were obtained from ICN Pharmaceuticals and from Schwarz/Mann, respectively.

Incubation conditions for progesterone production. Ovarian cells $\left(6 \times 10^{\frac{1}{6} \mathrm{cel} 1 \mathrm{~s} / \text { tube) }}\right.$ were incubated in Eagle's Minimal Essential Medium and Earle's salts (Medium 109) containing $0.1 \%$ bovine serum albumin (Sigma RIA 
grade) in the presence of respective hormones or other agents $(400 \mu \mathrm{I})$ for 3 hours at $37^{\circ}$ in the atmosphere of $\mathrm{O}_{2}: \mathrm{CO}_{2}(95: 9 \% \mathrm{v} / \mathrm{v})$. Following incubation, the reaction was stopped by placing the sample tubes in a boiling water bath for $3 \mathrm{~min}$, and $0.6 \mathrm{ml}$ water and $10 \mu \mathrm{T}(10,000 \mathrm{CPM})$ of $\left[1,2-{ }^{3} \mathrm{H}\right)$ progesterone (to monitor recovery) were added and samples left in cold overnight. On the following day samples were extracted with petroleum ether and assayed for progesterone by radioimmunoassay as described earlier $(7,8)$.

Binding of hCG to ovarian cells was carried out as described earlier (8). Ovarian cells were incubated in $0.4 \mathrm{ml}$ of Medium 109 containing $0.1 \%$ BSA, $\left[{ }^{125} \mathrm{I}\right] \mathrm{hCG}(160,000 \mathrm{CPM})$, and where required appropriate concentrations of mixed gangliosides or unlabelled choriogonadotropin. After incubation at $37^{\circ}$ in an atmosphere of $\mathrm{O}_{2}: \mathrm{CO}_{2}(95: 5 \% \mathrm{v} / \mathrm{v})$ for $60 \mathrm{~min}$, the binding was terminated by dilution $(3: 1)$ with cold medium and centrifuged at $4^{\circ}$ for 3 minutes at $4000 \times \mathrm{g}$. The medium was removed, and the pelleted cells were washed twice with $1 \mathrm{ml}$ of fresh media and counted directly in a gamma counter (Searle Analytic Model 1195). Non-specific binding of [125I] incubating ovarian cells with 1000-fold excess of unlabelled hormone. The [125I] ${ }^{12} \mathrm{CG}$ was prepared by iodinating hCG $\left(11,400 \mathrm{IU} \mathrm{mg}^{-1}\right)$ by the ChIoramine-T method to a specific activity of approximately $40-50 \mu \mathrm{Ci} \mu \mathrm{g}^{-1}$. Nonspecific binding was $0.2-0.4 \%$ of the total counts added. Specific binding was computed as the counts bound in the absence of unlabelled hCG minus the nonspecific binding. Specific binding of $\left[{ }^{125} \mathrm{I}\right] \mathrm{hCG}$ to isolated plasma membranes was carried out as described previously $(5,6)$.

\section{$\underline{\text { RESULTS }}$}

Isolated rat ovarian cells responded to incubation for $3 \mathrm{~h}$ with hCG $(10 \mathrm{ng} / \mathrm{ml})$, cholera enterotoxin $(100 \mathrm{ng} / \mathrm{ml}), 8 \mathrm{Br}$-cAMP $(2.5 \mathrm{mM})$ and $B t_{2}$-CAMP $(2.5 \mathrm{mM})$ with a 45 to 60 -fold increase in progesterone production. (Data not shown.)

Fig. I illustrates cholera enterotoxin and hCG stimulated time and doseresponse study for progesterone production. In the absence of either toxin or hormone no increase in progesterone production was detectable (6 pg. $\mu \mathrm{g}$ DNA $\left.{ }^{1}\right)$ even after $3 \mathrm{~h}$ of incubation. Stimulation of progesterone production in response to cholera enterotoxin was followed by a lag period. The duration of this lag period, however, was dependent upon the concentration of the enterotoxin used. With maximally stimulating dose of enterotoxin i.e., $1 \mu \mathrm{g} \cdot \mathrm{ml}^{-1}$, a significant elevation in progesterone synthesis was not observed until 90 minutes. In contrast, hCG stimulated steroidogenesis showed only 20-30 minutes lag period depending upon the concentration of the hormone employed.

Table 1 and Fig. 2 summarize the results of several experiments in which the effect of gangliosides were examined on $h C G, L H$ and cholera enterotoxin stimulated steroidogenesis. Preincubation of cholera enterotoxin with a mixture 


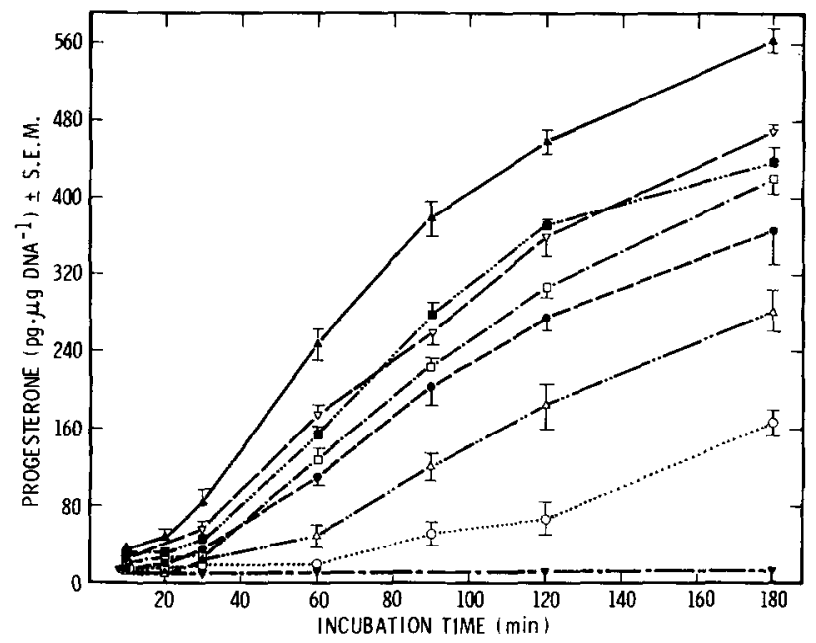

Fig. 1. Effect of varying incubation time on hCG and cholera enterotoxin stimulated progesterone synthes is in ovarian cells.

Ovarian cells $\left(3 \times 10^{6}\right.$ cells) were incubated with indicated concentrations of toxin or hormone for varying time periods up to $3 \mathrm{hrs}$. Other details were same as described under Materials and Methods. $\nabla$ none; $0 . . .0$ cholera enterotoxin $\left(0.25 \mathrm{ng} . \mathrm{ml}^{-1}\right) ; \Delta-\cdots-\Delta$ cholera enterotoxin $\left(2.5{\left.\mathrm{ng} . \mathrm{m}^{-1}\right)}^{-1}\right)$.... cholera enterotoxin

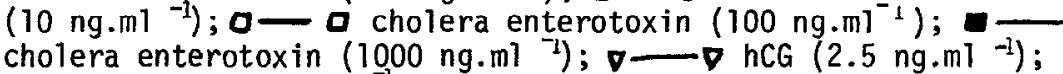
cholera enterotoxin $(1000$

of highly purified gangliosides completely blocked the subsequent steroidogenic response (Fig. 2). In contrast, under identical conditions preincubation of hCG or LH with gangliosides did not alter progesterone production to any significant extent (Table 1, Fig. 2). Different concentrations of gangliosides up to $1 \mathrm{mg} . \mathrm{ml}^{-1}$ used in the present experiments were completely ineffective in preventing gonadotropin-induced physiological response (Table 1). Results presented in Table 2 al so show that mixed gangliosides did not prevent the specific binding of [125I]hCG to the ovarian cells or to membranes prepared from the ovary. Similarly preincubation of $\left[{ }^{125}\right.$ I] hCG with mixed gangliosides did not alter the binding the hormone to ovarian cell surface receptor. Furthermore there was no inhibition of choriogonadotropin binding when gangliosides were preincubated with the ovarian cells prior to incubation with [125I]hCG (data not shown). 


\section{TABLE 1}

Effect of different concentrations of mixed gangliosides on hCG, LH and cholera enterotoxin-stimulated steroidogenesis in rat ovarian cells.

HCG, $L H$, and cholera enterotoxin were incubated with different concentrations of highiy purified mixed gangliosides in $300 \mu \mathrm{l}$ of Medium 109 containing $0.1 \%$ BSA at $25^{\circ}$ for $30 \mathrm{~min}$. Following incubation, $0.1 \mathrm{ml}$ ovarian cells ( $\left.4 \times 10^{6} \mathrm{cell} / \mathrm{s}\right)$ were added and incubation continued for an additional $3 \mathrm{hrs}$ at $37^{\circ}$ in the presence of $\mathrm{CO}_{2}: \mathrm{O}_{2}(5: 95 \% \mathrm{v} / \mathrm{v})$. After the second incubation, the samples were processed for progesterone radioimmunoassay as described under Materials and Methods. The preparation of gangi iosides used contained $47 \% \mathrm{G}_{\mathrm{O}}, 25 \% \mathrm{G}$ $16 \% \mathrm{G}_{\mathrm{DI}}$, and $12 \% \mathrm{G}_{\mathrm{M}}$. Gangliosides are designated according to sisennerhol (25). The concentrations expressed are the final concentrations in the incubation medium.

\begin{tabular}{|c|c|c|c|c|}
\hline \multirow[b]{2}{*}{$\begin{array}{l}\text { Mixed } \\
\text { Gangl iosides } \\
\left(\mu g . \mathrm{m}^{-1}\right)\end{array}$} & \multicolumn{4}{|c|}{ Progesterone (pg. $\left.\mu \mathrm{g} \mathrm{DNA}^{-1}\right) \pm$ S.E.M. } \\
\hline & None & 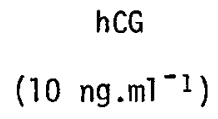 & $\begin{array}{c}\text { LH } \\
(\mathrm{NIH}-\mathrm{LH} \quad \mathrm{Bg}) \\
\left.50 \mathrm{ng} \cdot \mathrm{ml}^{-1}\right)\end{array}$ & $\begin{array}{c}\text { Cholera } \\
\text { Enterotoxin } \\
\left(100 \mathrm{ng}^{-1} \mathrm{~m}^{-1}\right)\end{array}$ \\
\hline 0 & $19.5 \pm 0.7$ & $588 \pm 40$ & $253 \pm 17$ & $454 \pm 36$ \\
\hline 25 & $19.2 \pm 1.4$ & $545 \pm 34$ & $240 \pm 18$ & $31 \pm 8$ \\
\hline 250 & $18.6 \pm 1.6$ & $632 \pm 44$ & $239 \pm 18$ & $24 \pm 2$ \\
\hline 500 & \pm 1 & $666 \pm 44$ & $271 \pm 14$ & \\
\hline 1000 & \pm 1.8 & $620 \pm 18$ & $224 \pm 5$ & \\
\hline
\end{tabular}

\section{DISCUSSION}

The present studies were carried out to delineate the functional role of gangliosides in receptor medicated gonadotropin action leading to physiological response in ovarian cells. To evaluate this possibility we have also investigated the effect of cholera enterotoxin on steroidogenes is in ovarian cells. In the present studies we have employed choleratoxin as a probe as this agent has been shown to bind $G_{M 1}$ in some manner (18-22) resulting in the activation of cAMP medicated metabolic processes in several biological systems $(12,13)$. In the present studies, incubation of ovarian cells with cholera exterotoxin resulted in the stimulation of progesterone production, and this stimulation was comparable to that produced by hCG. In agreement with the characteristics of choleragen response demonstrated in a variety of tissues $(12,23,24)$ the 


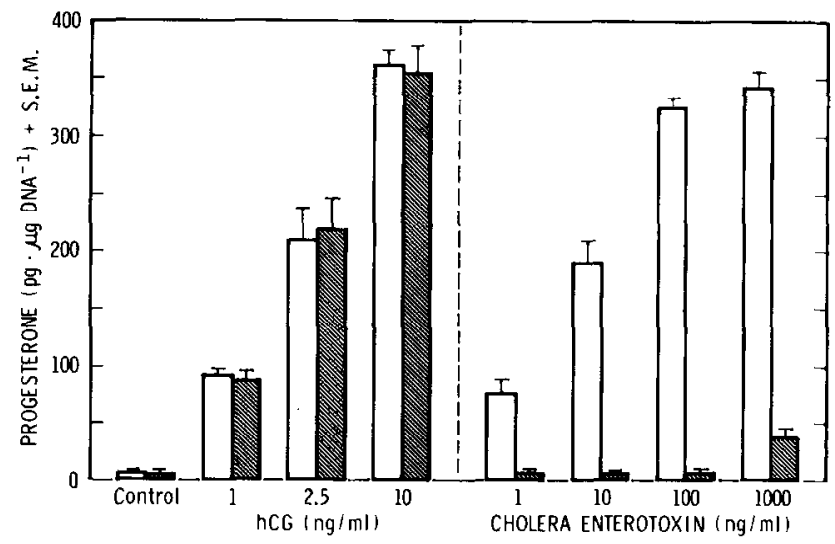

Fig. 2. Differential effect of mixed gangliosides on hCG and cholera enterotoxin stimulated progesterone production in ovarian cells.

Incubation conditions were similar to that described under Materials and Methods with the exception that indicated concentrations of mixed gangliosides under the conditions described in Table 1 . Following first incubation, $0.1 \mathrm{ml}$ ovarian cells $\left(2.6 \times 10^{6}\right.$ cells) were added and incubation continued for 3 hrs. The samples were then processed for progesterone quantitation by radioimmunoassay. Open bar, without gangliosides; hatched bar, with mixed gangliosides $\left(250 \mu \mathrm{g} . \mathrm{ml}^{-1}\right)$.

stimulation of progesterone production also showed a lag period.

Since gangliosides are cell membrane constituents, whose carbohydrate portion faces the outside of the cell membrane, we considered the possibility that the gonadotropin-ganglioside interaction may involve binding to the carbohydrate moiety of the gangliosides on the cell membrane. The present studies however clearly demonstrate that gangliosides did not modulate LH and hCG stimulated steroidogenesis, while these agents completely blocked the cholera enterotoxin-stimulated progesterone production. The failure of gangliosides to block [125I]hCG binding to rat ovarian cells further suggests that gonadotropin receptors in ovary are very specific and hormone receptor interaction may represent a complex phenomenon. In this respect our results are quite different from those previously reported for testis plasma membranes $(16,17)$, in which gangliosides $G_{D 1 a}, G_{D 1 b}, G_{T 1}$ and $G_{M I}$ have been shown to interact with hCG and LH. The experimental conditions in our studies were such that the type 


\section{TABLE 2}

Lack of effect of mixed gangliosides on specific binding of $\left[{ }^{125} \mathrm{I}\right] \mathrm{hCG}$ to ovarian cells and isolated plasma membranes.

Incubations conditions were same as described under Materials and Methods.

\begin{tabular}{|c|c|c|}
\hline & Additions & {$\left[{ }^{125} \mathrm{I}\right]$ hCG Bound } \\
\hline \multirow[t]{3}{*}{ I. } & Intact cells & $\mathrm{CPM} / 100 \mu \mathrm{g}$ DNA \pm SEM \\
\hline & None & $13907 \pm 252$ \\
\hline & $\begin{array}{r}25 \\
75 \\
150 \\
250 \\
500 \\
1000\end{array}$ & $\begin{array}{l}14137 \pm 145 \\
13885 \pm 497 \\
13884 \pm 239 \\
13083 \pm 388 \\
12962 \pm 306 \\
13908 \pm 110\end{array}$ \\
\hline \multirow[t]{3}{*}{ II. } & Isolated plasma membranes & $\mathrm{CPM} / \mathrm{mg}$ Protein $\pm \mathrm{SEM}$ \\
\hline & None & $22806 \pm 477$ \\
\hline & $\begin{array}{lr} & 17 \\
& 33 \\
167\end{array}$ & $\begin{array}{l}23733 \pm 149 \\
21120 \pm 638 \\
20684 \pm 284\end{array}$ \\
\hline
\end{tabular}

and amount of mixed gangliosides employed were not limiting. The inhibition of cholera enterotoxin stimulated steroidogenesis by gangliosides further suggests that these agents were effective depending upon the inducer employed.

These results thus suggest that in rat ovarian cells binding of $\left[{ }^{125} \mathrm{I}\right] \mathrm{hCG}$ and subsequent hormonal response are not influenced by gangliosides. Furthermore, these findings suggest that gangliosides are not involved in gonadotropin binding to ovarian cell surface receptors and subsequent mediation of physiological response.

\section{REFERENCES}

1. Gospodarowicz, D. (1973) J. Biol. Chem. 248, 5042-5049.

2. Haour, F. and Saxena, B.B. (1974) J. BioT. Chem. 249, 2195-2205.

3. Rao, C.V. (1974) J. Biol. Chem. 249, 2864-2872.

4. Menon, K.M.J. and Kiburz, J. (1974) Biochem. Biophys. Res. Commun. 56, 363-371. 
5. Azhar, S. and Menon, K.M.J. (1976) J. Biol. Chem. 251, 7398-7404.

6. Azhar, S. Hajra, A.K. and Menon, K.M.J. (1976) J. Biol. Chem. 251, 7405-7412.

7. Kawano, A., Gunaga, K.P. and Menon, K.M.J. (1975) Biochim. Biophys. Acta $385,88-100$.

8. CTark, M.R. and Menon, K.M.J. (1976) Biochim. Biophys. Acta 444, 23-32.

9. Azhar, S., Clark, M.R. and Menon, K.M.J. (1976) Endocr. Res. Commun. 3 , 93-104.

10. Clark, M.R., Azhar, S. and Menon, K.M.J. (1976) Biochem. J. 158, 175-182.

11. Azhar, S. and Menon, K.M.J. (1978) Biochem. Biophys. Res. Commun. 81, 205-211.

12. Finkelstein, R.A. (1973) CRC Crit. Rev. Microbiol. 2, 553-623.

13. Sharp, G.W.G. (1973) Ann. Rev. Med. 24, 19-35.

14. Ledley, F.D., Mull in, B.R., Lee, G., Aioj, S.M., Fishman, P.H., Hunt, L.T. Dayhoff, M.0. and Kohn, L.D. (1976) Biochem. Biophys. Res. Commun. 69, 852-859.

15. Kurosky, A., Markel, D.E., Peterson, J.W. and Fitch, W.M. (1977) Science 195, 299-30i.

16. Lee, G., Aloj, S.M., Brady, R.O. and Kohn, L.D. (1976) Biochem. Biophys. Res. Commun. 73, 370-377.

17. Lee, G., Aloj, S.M. and Kohn, L.D. (1976) Biochem. Biophys. Res. Commun. $77,434-441$.

18. Cuatrecasas, P. (1973) Biochemistry 12, 3558-3566.

19. Holmgren, J., Lonnroth, I. and Svennerholm (1973) Infect. Immun. $\underline{8}$, 208-214.

20. Pierce, N.F. (1973) J. Exp. Med. 137, 1009-1023.

21. van Heyningen, S. (1974) Science 183, 656-657.

22. Bennett, V., Craig, S., Hol lenberg, M.D., O'Keefe, E., Sahyon, N. and Cuatrecasas, P. (1976) J. Supr. Mol. Str. 4, 99-120.

23. Bennet, V. and Cuatracasas, P. (1975) J. Membrane Biol . 22, 29-52.

24. Finkelstein, R.A. (1976) in Mechanisms in Bacterial Toxicology (Bernheimer, A.W., ed.) pp. 54-84, John Wiley and Sons, New York.

25. Svennerhoim. L. (1963) J. Neurochem. 10, 613-623. 